Institute of $\mathbf{F}_{\text {ood and }} \mathbf{A}_{\text {gricultural }} \mathbf{S}_{\text {ciences }}$

\title{
Prioritizing Citrus Nutrient Management Decisions ${ }^{1}$
}

Thomas A. Obreza ${ }^{2}$

\section{Introduction}

Citrus nutrient management can be divided into four components: Monitoring, program development, application, and evaluation. Monitoring can be qualitative (visual observations of tree performance), or quantitative (laboratory analysis of soil and/or leaf tissue samples). In program development, the grove manager decides what type of fertilizer sources will be used, and the rate, timing, and frequency at which nutrients will be applied. The application phase centers on methods used to place the nutrients (e.g. spreading dry fertilizer, applying suspension fertilizers with a herbicide boom, injecting solution fertilizers into the irrigation system, or spraying soluble nutrients on leaves). Following fertilizer application, the evaluation step determines whether the desired crop response was achieved, usually by evaluating tree growth, fruit yield, and fruit quality.

Ideally, a citrus nutrient management plan will provide maximum citrus yield and quality while minimizing the potential for water quality impairment. Nutrient management can become a complex task as a citrus grove manager considers the many factors that affect the choices of nutrient rate, source, placement, form, and application timing. In economic conditions that require maximum efficiency of grove operations, managers are required to accomplish more tasks with fewer people, reduced resources, and less time. Activities must be prioritized, but when faced with a multitude of decisions to make, how does a manager decide where to place the most emphasis?

\section{Citrus Sensitivity to Individual Nutrients}

Citrus tree sensitivity to shortages or excesses of individual nutrients differs depending on the nutrient. For example, observations of mature citrus trees in the field tell us that manganese deficiency does not affect production nearly as much as nitrogen deficiency. Similarly, an excess of boron affects fruit quality more than an excess of magnesium. For the purpose of this discussion, water is also considered as a nutritional factor because nutrient and water management cannot be separated. The task then becomes one of ranking the importance of different nutritional factors to determine how to prioritize their management.

In the 1960s, Dr. R. C. J. Koo and Dr. R. L. Reese of the UF-IFAS Citrus Research and Education Center in Lake Alfred grew Pineapple orange trees on a previously non-fertilized deep sandy soil and

1. This document is SL 199, a fact sheet of the Soil and Water Science Department, Florida Cooperative Extension Service, Institute of Food and Agricultural Sciences, University of Florida. First printed: January 2003. Please visit the EDIS Web site at http://edis.ifas.ufl.edu.

2. Thomas A. Obreza, Professor, Soil and Water Science Department, Florida Cooperative Extension Service, Institute of Food and Agricultural Sciences, University of Florida, Gainesville, 32611-0290.

The Institute of Food and Agricultural Sciences is an equal opportunity/affirmative action employer authorized to provide research, educational information and other services only to individuals and institutions that function without regard to race, color, sex, age, handicap, or national origin. For information on obtaining other extension publications, contact your county Cooperative Extension Service office. Florida Cooperative Extension Service/Institute of Food and Agricultural Sciences/University of Florida/Christine Taylor Waddill, Dean. 
implemented a set of treatments where they omitted single essential mineral nutrients from the fertilizer program. The twelve nutrients they studied were macronutrients nitrogen $(\mathrm{N})$, phosphorus $(\mathrm{P})$, and potassium $(\mathrm{K})$; secondary nutrients calcium $(\mathrm{Ca})$, magnesium $(\mathrm{Mg})$, and sulfur $(\mathrm{S})$; and micronutrients manganese $(\mathrm{Mn})$, zinc $(\mathrm{Zn})$, copper $(\mathrm{Cu})$, boron $(\mathrm{B})$, and molybdenum (Mo). The $\mathrm{N}$ omission treatment was not zero $\mathrm{N}$, but was half of full $\mathrm{N}$ fertilization. They found that citrus yield was most sensitive to omission of $\mathrm{N}, \mathrm{P}$, and $\mathrm{K}$, and least sensitive to omission of micronutrients (Figure 1). One of the most important aspects of this study was that even on a sandy soil with poor native fertility, it took 7 years for omission of micronutrients to show negative effects.

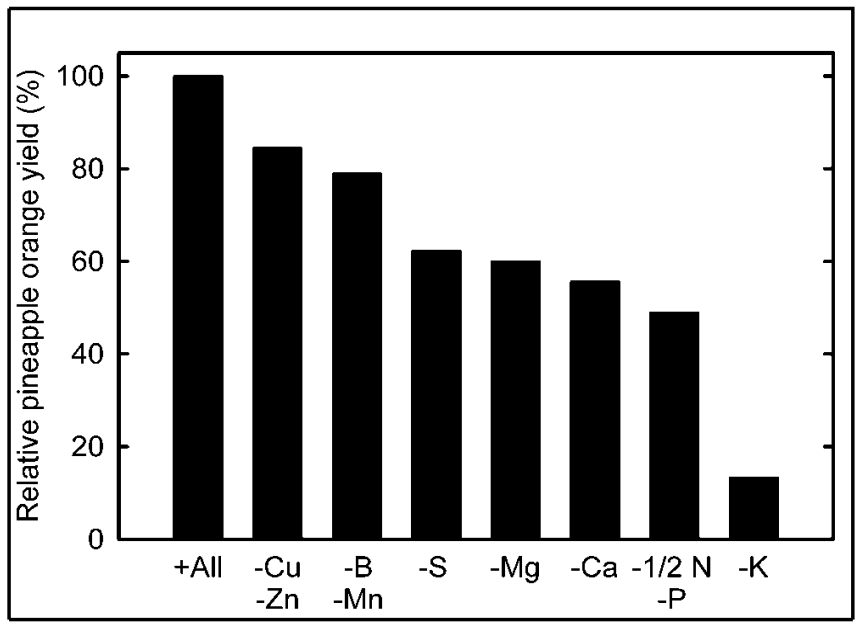

Figure 1. Sensitivity of pineapple orange trees planted on a native ridge sand to omission of single nutrient elements. The "+All" treatment received all essential nutrients; the $\mathrm{N}$ omission treatment was half of the $\mathrm{N}$ applied in the "+All" treatment. (From Koo and Reese, Proc. Fla. State Hort. Soc., 1971).

\section{Nutrient Accumulation and Loss}

As a young citrus grove gets older, some nutrients applied in fertilizers and soil amendments will tend to accumulate in the soil, while others will mostly leach out of the root zone with rain or irrigation water if not taken up by the trees. The extent to which soil nutrient accumulation takes place will depend on the nutrient, its application rate, and the characteristics of the soil. For sandy Florida soils, the following are rules of thumb regarding nutrient accumulation or leaching:
- $\mathrm{Cu}, \mathrm{Zn}$, and $\mathrm{Mn}$ will accumulate in the root zone as a result of fertilizers applied to the soil or tree foliage. Soil accumulation of $\mathrm{Cu}$ resulting from frequent $\mathrm{Cu}$-based fungicide applications can be particularly high.

- $\mathrm{Ca}$ and $\mathrm{Mg}$ will accumulate in the root zone as a result of calcitic or dolomitic limestone applications, or soil-applied fertilizers.

- As the amount of organic matter or clay in the soil increases, the accumulation of $\mathrm{S}$ applied as a component of many fertilizers will increase.

- P will normally accumulate in the root zone unless the soil is extremely sandy and low in organic matter.

- N, K, and B are nutrients that are poorly held by sandy soils and will be leached by rainfall or excessive irrigation. Thus, they usually must be applied as fertilizer every year.

Nutrient accumulation in the soil is one of several factors that determine the availability of nutrients to plants. Just because the concentration of a nutrient has increased in the soil does not mean that its availability has concurrently increased. Other factors including soil $\mathrm{pH}$, water management, and root system health can significantly influence plant nutrient uptake.

\section{Fertilization Experiments in the Flatwoods}

During the last decade, fertilization experiments with mature flatwoods citrus trees that were well fertilized in their non-bearing years showed that good water management alone provided about $30 \%$ to $40 \%$ of maximum yield. When sufficient amounts of $\mathrm{N}$ and $\mathrm{K}$ fertilizer were combined with good water management, production reached or surpassed $90 \%$ of its maximum. Thus, the remaining $10 \%$ or less of a grove's yield potential was attributed to the combined effect of the remaining essential elements. It is important to reiterate that the groves where $\mathrm{N}$ and $\mathrm{K}$ experiments were conducted had lime, $\mathrm{P}$, and micronutrient fertilizers applied to them when the trees were young. 


\section{Prioritizing Decision-Making}

If citrus is most sensitive to water, $\mathrm{N}$, and $\mathrm{K}$, then nutrient management decisions should concentrate on improving their management before considering other factors. For example, if a grove is watered using a micro-irrigation system, how uniform is the water distribution from emitter to emitter? Are there any plugged sprinklers or drippers? If a grove manager chooses to fertigate a significant portion of the $\mathrm{N}$ and $\mathrm{K}$ (typically considered as a Best Management Practice for nutrients), it is important to frequently check the irrigation system for water distribution uniformity. The Mobile Irrigation Laboratories operated by the USDA-NRCS can measure irrigation system performance. If the system tests below $80 \%$ emission uniformity, corrective action should be implemented to even out and improve the nutrient distribution.

What about $\mathrm{N}$ and $\mathrm{K}_{2} \mathrm{O}$ fertilizer rates? In citrus fertilization research conducted on southwest Florida flatwoods soils, maximum yield has been obtained using $\mathrm{N}$ rates within the currently recommended range of 160 to $240 \mathrm{lbs} N$ per acre per year. When coated, controlled-release fertilizers were applied in place of standard, water-soluble materials, rates could be lowered because nutrient use efficiency increased. Additional work with $\mathrm{P}$ and $\mathrm{K}$ fertilizer rates suggests that $\mathrm{K}$ influences citrus yield on the same order of magnitude as N. However, citrus is not very sensitive to $\mathrm{P}$ fertilization on flatwoods soils, especially if $\mathrm{P}$ has accumulated in the soil from previous fertilizer applications.

\section{Summary}

When prioritizing nutrient management decisions, grove managers should recognize the relative sensitivity of citrus to various nutritional factors in their groves and concentrate on improving the most sensitive ones first. Doing so will allow more time to deal with other citrus management issues. 